\title{
A Preliminary Survey of Amphibians and Reptiles in Around Gulbarga University Campus, Karnataka, India
}

\author{
Murali Jadesh, Parshuram Kamble, K. Manjunath*, K. Ravikiran, \\ Sharanappa Padashetty \\ Department of Zoology, Gulbarga University, Gulbarga - 585106, Karnataka, India \\ *E-mail address: manjunathk2007@rediffmail.com
}

\begin{abstract}
The study involves survey of amphibian and reptile in and around Gulbarga University Campus. Survey was conducted from Jan 2012 to March 2013. The survey methods involved careful visual estimation of amphibians and reptilian in all the possible habitats present in the study area. The objective of the study included evaluate of species composition, relative abundance and distribution of amphibian and reptile of the chosen area. During survey a total of 16 species of herpetofauna identified belonging to 12 families, which includes 9 species of snakes, 4 species amphibians, 3 species of lizards.
\end{abstract}

Keywords: Amphibia; Reptilia; Gulbarga

\section{INTRODUCTION}

Reptiles and amphibians occupy a diverse range of habitats and microhabitats, found from deserts to grass-lands, from forests to oceans and from hills to our own houses. India is very rich in herpetofaunal diversity (Anukul Nath et al., 2012). There are more than 518 species of reptiles (Aengals et al., 2011) and 314 species of amphibians (Dinesh et al., 2011) found in India. Habitat destruc-tion and the resulting fragmentation of population is the most important factor affecting the amphibian popula-tion (Adams, 1999). Population size of amphibians are unknown for almost all species, and, as significance, recent trends in population sizes also remain unknown (Dutta, 1997). Generally, most of the fundamental data on species biology and ecology are lacking (Vasudevan et al., 2001). Investigations of amphibian species are receiving considerable attention because of the pro-posed role of amphibians as indicators of ecosystem deterioration (Wake, 1991). Amphibians play a very important role in the food chain of both terrestrial and aquatic ecosystems. The general ecological importance of amphibians lies in them being predators acting as primary and secondary carnivores on insects, some of which are crop pests or disease vectors (Behangana 2004).

It is expected that the world population growth in the next thirty years will be mostly concentrated in the urban areas (United Nations, 2004) leading to even more rapid degradation of pockets of remnant natural habitats. 
Amphibians are widely considered to be useful as indicator species (Welsh and Ollivier 1998, Sheridan and Olson 2003). In India, besides the forest floor and stream communities of amphibians, there are few widely spread species in human modified and agro ecosystems (Daniels, 2005). The human modified ecosystems of the plains as that in rural, cultivated and semi urbanized areas attract number of species of frog and toads.

Hence, the purpose of this study is to provide species composition of amphibian and reptilian community in Gulbarga University Campus.

\section{STUDY AREA}

The study regions include Gulbarga university campus. Gulbarga district is located on the North-Eastern part of Karnataka. Geographically it lies between 1704 ' - 77 42' longitude and 16 12' -17 46' latitude and placed 45meters above the mean sea level. Gulbarga possesses a typical climate of South Indian Pennisula with semi-arid conditions, with temperature between $14{ }^{\circ} \mathrm{C}$ in winter $-45^{\circ} \mathrm{C}$ in summer and the average rainfall being $702 \mathrm{~mm}$. The main campus is located 10 kilometres $(6.2 \mathrm{mi})$ from the Gulbarga city centre and is situated on 860 acres of land.

\section{METHODOLOGY}

Random surveys were conducted in and around study area to document the amphibian and reptile species. The calls during the night time helped to locate and collect several amphibian species like Dut-taphrynus melanostictus

Diurnal forms were collected between dawn and midday. Night observations were made wherever possible. The survey methods involve extensive survey and careful visual estimation of amphibians in all possible habitats. Path ways were scanned, leaf-litter within the area was turned, bricks were lifted and searched underneath, shrubs and grass were shaken and gleaned, fallen logs turned and searched underneath, tree holes, temporary water pools were searched for the presence of amphibians. The species were identified by using Smith (1943), Daniel (2002) and Daniels (2005).

The survey of amphibian was made at night, between $1800 \mathrm{hrs}$ to $2200 \mathrm{hrs}$ thrice a week during the month of Jan 2012 to March 2013. Apart from that, reptiles were surveyed during December 2012 to January 2013 including all the opportunistic sightings, road kills and rescue calls. The species were identified by using Smith (1943) and Das (2002).

\section{OBSERVATIONS \& RESULTS}

A total of 16 species of herpetofauna identified belonging to 12 families, which includes 9 species of snakes, 4 species amphibians, 3 species of lizards (Table 1) (Table 2). Among amphibians, abundance of Duttaphrynus melanostictus was high compare to other species.

The species which were found to breed were Duttaphrynus melanostictus, Hoplobatrachus tigrinus and Kaloula taprobanica. A Street light attracts lots of flying insects particularly after the rain. These lights, in turn, visited by number of frogs and toads that feast on the insects that fall on the ground. K. taprobanica and D. melanostictus often found to feed on insects under the light. 
Among the lizards, Ca-lotes versicolor was more frequent. Whereas Eutropis carinata were more common.

Snakes were encountered in almost all habitats present in the study area. Among them Ahaetulla nasuta, Ptyas mucosa were more frequently encountered than the others. Two species of venomous snakes identified were Naja naja and Daboia russelii. Sev-eral of them were rescued from residential houses, shops and open well; whereas D. russelii was rare compare to other venomous species found in the study area.

\section{DISCUSSION AND CONCUSIONS}

The present study reveals that study area includes rich diversity of herpetofauna. A total of 16 species of herpetofauna identified belonging to 12 families, which includes 9 species of snakes, 4 species amphibians, 3 species of lizards. High abundance of D. melanostictus compared to other species which may lead to the lower stability in this community. $D$. melanostictus is cosmopolitan in distribution (Dutta, 1997) and is known to occur in a variety of habitats, especially in disturbed areas (Inger et al., 1984).

However, the pre-sent study on amphibian community is just a model to show the microhabitat occupancy by the amphibians in the human settlements and competition among them as, spatial resource partitioning may be one of the chief indicators of interspecific interactions.

In our study we found 9 species of snakes in and around human habitation which initiates human-snake conflict quite often. Naja naja were more likely to create human-snake conflict in the study area. In most cases, non-venomous snakes were found to be the victims in the human-snake conflict, as most of the people not able to distinguish between venomous and non-venomous snakes. Lack of awareness was the main reason for the killing of snakes (Nath et al., 2011).

Awareness programs are needed to be conducted in order to make people acquainted with herpetofauna and their importance for a balanced eco-system. Snake bite management is another issue which is to be taken up more seriously, although people were seen to reach hospitals immediately after the snake bite.

Therefore it's necessary to aware the people regarding the importance of the area in herpetofaunal research.

Table 1. List of Amphibians species recorded during 2012-13 at Gulbarga University Campus.

\begin{tabular}{|c|c|c|c|}
\hline S. No & Order & Family & Scientific name \\
\hline 1 & Anura & Bufonidae & Duttaphrynus melanostictus \\
\hline & & Dicroglossidae & Hoplobatrachus tigerinus \\
\hline & & Microhylidae & Kaloula taprobanica \\
\hline & & & Microhyla ornata \\
\hline
\end{tabular}


Table 2. List of Reptilians species recorded during 2012-13 at Gulbarga University Campus.

\begin{tabular}{|c|c|c|c|}
\hline S. No & Order & Family & Scientific name \\
\hline 1 & Squamata & Agamidae & Calotes versicolor \\
\hline & & Gekkonidae & Hemidactylus flaviviridis \\
\hline & & Scincidae & Eutropis carinata \\
\hline & & Boidae & Eryx johnii \\
\hline & & Pythonidae & Python molurus \\
\hline & & Colubridae & Ahaetulla nasuta \\
\hline & & & Coelognathus helena \\
\hline & & & Lycodon striatus \\
\hline & & & Oligodon arnensis \\
\hline & & Elapidae & Ptyas mucosa \\
\hline & & Viperidae & Daboia russelii \\
\hline
\end{tabular}

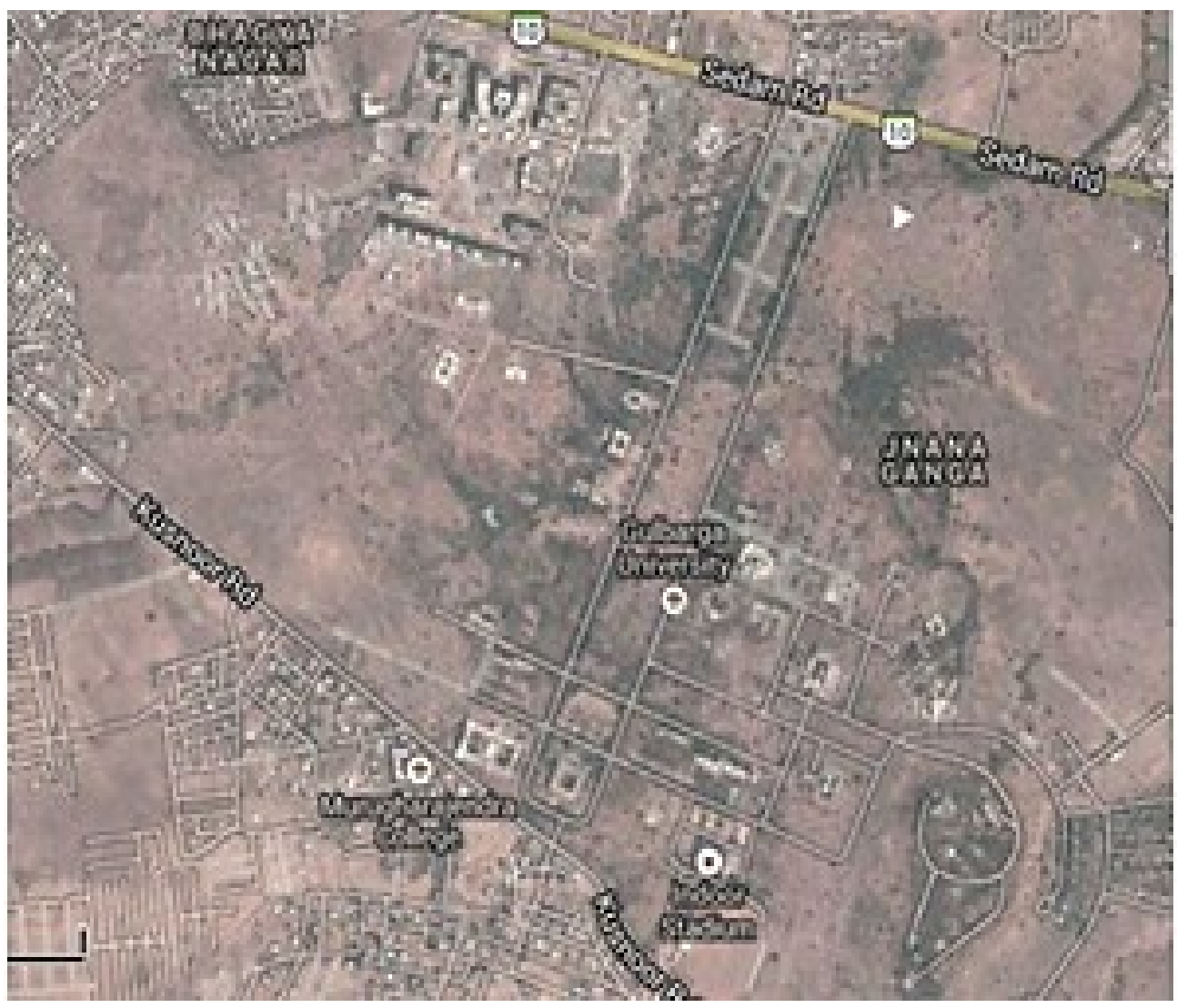

Figure 1. Study area of Gulbarga University Campus. 


\section{Reference}

[1] Adams M., Journal of Wildlife Management 63 (1999) 1162-1171.

[2] Aengals R., Sathish Kumar V.M., Palot M. J. (2011). Updated Checklist of Indian Reptiles. Zoological Survey of India. zsi.gov.in/ checklist/ Reptiles.

[3] Anukul Nath, et al., Asian Journal of Conservation Biology 1(2) (2012) 78-85.

[4] Behangana M., African Journal Ecology 42 (2004) 51-56.

[5] Daniel J. C. (2002). The Book of Indian Reptiles and Amphibians. Bombay Natural History Society, Oxford University Press, Mumbai: 238 pp.

[6] Daniels R. J. R. (2005). Amphibians of Peninsular India. Universities Press, Hyderabad, India, 286.

[7] Das I. (2002). A Photographic Guide to Snakes and other Reptiles of India. New Holland publications, London, UK: 144 pp.

[8] Dinesh K.P., Radhakrishnan C., Gururaja K.V., Deuti K., Bhatta G. (2011). A Checklist of Amphibia of India. Zoological Survey of India: zsi.gov.in/checklist/Amphibia.

[9] Dutta S. K. (1997). Amphibian species of India and Sri Lanka (checklist and bibliography). Odyssey Publishing House Bhubaneswar. xiii $+342+$ xxii pp.

[10] http://earth.google.com/intl/en/download-earth.html assessed on 9-2-2013

[11] Inger R.F., Shaffer H.B., Koshy M., Badke R. Journal of Bombay natural History Society 81 (1984) 406-427; 551-570.

[12] Nath A. Singha H., Das A., Rep tile Rap 13 (2011) 9-13.

[13] Sheridan C.D., D.H. Olson, Canadian Journal of Forest Research 33 (2003) 1452-1477.

[14] Smith M. A. (1943). Fauna of British India, including Ceylon and Burma. Vol. III Serpentes. Taylor and Francis publications, London: 583.

[15] United Nations (2004). World Urbanization Prospects, the 2003 Revision. United Nations Publication sales No. E.04. XIII. 6.

[16] Vasudevan K., Kumar A., Chellam R., Current Science 80 (3) (2001) 406-412.

[17] Wake D. B., Science 253 (1991) 860.

[18] Welsh H. H. J., L. M. Ollivier, Ecological Applications 8 (1998) 1118-1132. 